\title{
Study of Electrochemical Properties of Soil and Nutrient Status of Rice and Maize based Cropping Sequences in Central Plain Zone of Uttar Pradesh
}

\author{
Rentapalli Balaji", Karam Husain and Uma Shankar Tiwari
}

Department of Agronomy, Chandra Shekhar Azad University of Agriculture and Technology, Kanpur, Uttar Pradesh, India

*Corresponding author

\section{A B S T R A C T}

\begin{tabular}{|l|}
\hline K e y w o r d s \\
$\begin{array}{l}\text { Electrochemical } \\
\text { properties, Cropping } \\
\text { sequence, Nutrient status }\end{array}$ \\
\hline Article Info \\
\hline $\begin{array}{l}\text { Accepted: } \\
\text { 04 October } 2018 \\
\text { Available Online: } \\
\text { 10 November } 2018\end{array}$ \\
\hline
\end{tabular}

An experiment was executed with ten crop sequences during 2010-17 at C.S. Azad University of Agriculture and Technology, Kanpur, Uttar Pradesh under All India Coordinating Research Project on Cropping systems. All these sequences were evaluated for their soil electrochemical and nutrient analysis. Results revealed that improvement in soil electrochemical properties ( $\mathrm{pH}, \mathrm{EC}$ and $\mathrm{OC}$ ) and available NPK content after harvest was achieved by Hyb. Rice-wheat-green gram $(\mathrm{G}+\mathrm{R})$ among four rice based cropping sequences, while these were achieved by Maize-garlic-green gram $(G+R)$ cropping sequence among six maize based cropping sequences. Maximum available nitrogen, phosphorus and potassium status $(263,14.90$ and $223 \mathrm{~kg} / \mathrm{ha}$ respectively) after harvest were recorded in Hyb. Rice-wheat-green gram $(\mathrm{G}+\mathrm{R})$ among rice based cropping sequences and among maize based cropping sequences, Maize-garlic-green gram $(\mathrm{G}+\mathrm{R})$ showed maximum available N, P and K of 259.2, 14.5 and $222 \mathrm{~kg} /$ ha respectively.

\section{Introduction}

Cropping system signifies the sequence of crops grown over a specific piece of cultivated land and to increase the benefits from the available resources. Therefore, the basic approach in an efficient cropping system is to increase production and economic returns (Yadav et al., 1998). A flexible cropping system helps in capturing economic opportunities and environmental realities (Gangwar et al., 2004) and in ensuring balanced farm growth at regional level (Reddy and Suresh 2009). Hence, selection of component crops needs to be suitably planned for efficient utilization of resource base and to increase overall productivity (Anderson, 2005). Higher annualized crop yields increase nutrient removal, which must be balanced by increased nutrient inputs to ensure optimal crop yield and quality while avoiding soil depletion. Furthermore, diversification of crops alters the pattern and degree of nutrient removal and influences microbiological activity and soil quality. Although cropping intensification and diversification will influence most plant nutrients, $\mathrm{N}$ and $\mathrm{P}$ are the nutrients most commonly deficient for crop production in the Plains and most likely to be affected by management practices. Cropping intensification increases crop residue return to the soil, which in turn increases the soil 
organic C pool. This can lead to higher soil organic matter levels and a greater potential for nutrient cycling, an effect that will increase with time. Cropping systems that include legumes have the potential for contributing $\mathrm{N}$ to following crops and may moderate $\mathrm{NO}_{3}$ levels in the soil to avoid potential for $\mathrm{NO}_{3}$ leaching. Phosphorus availability may be influenced by depletion or accumulation of $\mathrm{P}$, based on past cropping and fertilizer management. In addition, preceding crop may influence $P$ availability through residue effects and impacts on vesicular-arbuscular mycorrhizae activity. Synchrony of nutrient supply with crop demand is essential in order to ensure optimum crop yield and quality while avoiding negative environmental impacts.

It has been widely reported that most soils of the Indo-Gangetic Plain (IGP) have high K status due to continuing additions from rainfall, irrigation water, and release from Krich clay minerals (Dobermann et al., 1996a, 1996b, 1999). Several studies have shown, however, that intensive rice-based cropping systems, including rice-wheat (RW) (Timsina and Connor, 2001), may cause heavy depletion of soil NPK (BijaySingh et al., 2003; Yadvinder- Singh et al., 2005).

Extraction is especially large in these systems because straw is often harvested as well as grain, or is burnt to facilitate tillage (Timsina and Connor, 2001). Harvested straw finds important use in thatching, fuel, and animal fodder. Recent soil tests now show that many soils of the IGP, with available NPK concentrations are becoming deficient in soils despite originally high contents (Dobermann et al., 1999; Regmi et al., 2002; Srivastava et al., 2002; Bijay-Singh et al., 2003). Depletion of soil nutrients, NPK, is a possible cause of yield decline in long-term RW experiments in northwest India (Bhandari et al., 2003) and Nepal (Regmi et al., 2002).
Rice -wheat cropping system (RWCS) is the world's largest agricultural production system occupying around $12.3 \mathrm{~m}$ ha in India and around 85 percent of this area falls in IndoGangetic plains (IGP) (Ladha et al., 2003; Timsina and Connor, 2001). This system requires high input resources for higher productivity resulted higher cost per unit area and time. Following continuously the same system has adverse effect on soil health, ultimately decline in factor productivity of the system (Kumar and Yadav, 1993). So, diversification has been envisaged as a new strategy for enhancing and stabilizing productivity and soil health, making Indian agriculture competitive and increasing net farm income and economic security toward achieving the sustainable agricultural development. Both Rice-Wheat and MaizeWheat cropping systems are predominately practiced under irrigated as well as rainfed production system in lndo-Gangetic Plains. As a whole, cultivation of both rice and wheat crop is costly time consuming, energy exhaustive and tedious. Hence, there is an urgent need for diversification and intensification of cropping system in rice based cropping system by improving the productivity and profitability per unit area per unit time without jeopardizing the soil health. The inclusion of crops like oil seeds, pulse and vegetable will improve the economic condition of the farmers owing to higher price and higher volume of their main and byproducts. The legumes will also show favourable effect on soil health (Kharub et al., 2003).

\section{Materials and Methods}

The field experiment was conducted during 2010-17 at Student's Instructional Farm, C.S. Azad university of Agriculture and Technology, Kanpur under All India Coordinating Research Project on Cropping Systems to study the effect of rice and maize 
based cropping systems on soil fertility and soil electrochemical properties. The soil was neutral to slightly alkaline of alluvial type having $\mathrm{pH} 7.8$, EC $0.18 \mathrm{dsm}^{-1}, 0.55 \%$ organic carbon, available nitrogen $\left(223 \mathrm{kgha}^{-1}\right)$, low in available phosphorus $\left(14 \mathrm{kgha}^{-1}\right)$ and medium in available potash $\left(216 \mathrm{kgha}^{-1}\right)$. A total of ten cereal based crop (four rice based and six maize based) Rice-wheat $\left(\mathrm{T}_{1}\right)$, Hyb. Ricewheat $\left(\mathrm{T}_{2}\right)$, Hyb. Rice-wheat-green gram $(\mathrm{G}+\mathrm{R}) \quad\left(\mathrm{T}_{3}\right)$, Maize-wheat $\left(\mathrm{T}_{4}\right)$, Maizemustard-onion $\left(\mathrm{T}_{5}\right)$, Maize-mustard-green gram $(\mathrm{G}+\mathrm{R})\left(\mathrm{T}_{6}\right)$, Maize + green gram-potatowheat $\left(\mathrm{T}_{7}\right)$, Maize + black gram-potato-onion $\left(\mathrm{T}_{8}\right)$ Maize-garlic-green gram $(\mathrm{G}+\mathrm{R})\left(\mathrm{T}_{9}\right)$ and Scented rice-wheat-okra $\left(\mathrm{T}_{10}\right)$ sequences were tested. Before sowing, soil $\mathrm{pH}, \mathrm{EC}, \mathrm{OC}$, available $\mathrm{N}, \mathrm{P}$ and $\mathrm{K}$ content were recorded by their respective procedures. After harvest of each cropping sequence, soil samples were tested for nutrient removal by respective cropping sequence and how the electrochemical properties of soil were affected.

\section{Results and Discussion}

\section{Effect on soil electrochemical properties (after harvest)}

The data presented in the Table 1, indicates that soil electrochemical properties $(\mathrm{pH}, \mathrm{EC}$ and OC) after harvest of ten cereal based cropping sequences in Central Plain Zone of Uttar Pradesh. There was a little change in soil $\mathrm{pH}$ i.e. 0.1 unit either less or more in all crop sequences. EC was also changed slightly i.e. 0.01 units either less or more in all crop sequences. OC \% was improved well in crop sequences having green gram/black gram crop as a component crop of the crop sequence. Almost all crop sequences recorded improvement in soil organic carbon (Porpavai et al., 2011).

Table.1 Electrochemical properties of soil

\begin{tabular}{|c|c|c|c|c|c|c|}
\hline \multirow[t]{2}{*}{ Cropping Sequence } & \multicolumn{3}{|c|}{ Before sowing } & \multicolumn{3}{|c|}{ After harvest } \\
\hline & $\mathrm{pH}$ & $\mathrm{EC}\left(\mathrm{ds} \mathrm{m}^{-1}\right)$ & $\mathrm{OC}(\%)$ & $\mathrm{pH}$ & $\mathrm{EC}\left(\mathrm{ds} \mathrm{m^{-1 }}\right)$ & $\mathrm{OC}(\%)$ \\
\hline $\mathrm{T}_{1}$ :Rice-Wheat & 7.9 & 0.16 & 0.51 & 7.8 & 0.15 & 0.52 \\
\hline $\mathrm{T}_{2}$ : Hyb. Rice-Wheat & 7.8 & 0.15 & 0.53 & 7.8 & 0.15 & 0.54 \\
\hline $\begin{array}{l}T_{3}: \text { Hyb. Rice-Wheat- } \\
\text { Green gram }(G+R)\end{array}$ & 7.6 & 0.22 & 0.60 & 7.6 & 0.23 & 0.62 \\
\hline T4:Maize-Wheat & 7.8 & 0.16 & 0.52 & 7.7 & 0.16 & 0.53 \\
\hline $\begin{array}{l}\text { T5: Maize-Mustard- } \\
\text { Onion }\end{array}$ & 7.9 & 0.17 & 0.51 & 7.8 & 0.17 & 0.52 \\
\hline $\begin{array}{l}\text { T}_{6}: \text { Maize-Mustard- } \\
\text { Green gram }(\mathrm{G}+\mathrm{R})\end{array}$ & 7.7 & 0.23 & 0.58 & 7.6 & 0.24 & 0.60 \\
\hline $\begin{array}{l}\text { T: }: \text { Maize+Greengram- } \\
\text { Potato-Wheat }\end{array}$ & 7.8 & 0.20 & 0.55 & 7.8 & 0.21 & 0.56 \\
\hline $\begin{array}{l}\text { T8:Maize+Black gram- } \\
\text { Potato-Onion }\end{array}$ & 7.8 & 0.21 & 0.56 & 7.7 & 0.22 & 0.57 \\
\hline $\begin{array}{l}\text { T9: Maize-Garlic-Green } \\
\text { gram }(\mathbf{G}+\mathbf{R})\end{array}$ & 7.6 & 0.23 & 0.59 & 7.6 & 0.24 & 0.61 \\
\hline$T_{10}:$ Rice-Wheat-Okra & 7.8 & 0.16 & 0.51 & 7.7 & 0.15 & 0.53 \\
\hline
\end{tabular}


Table.2 Soil available nutrient status

\begin{tabular}{|c|c|c|c|c|c|c|}
\hline \multirow[t]{2}{*}{ Cropping Sequence } & \multicolumn{3}{|c|}{ Before sowing } & \multicolumn{3}{|c|}{ After harvest } \\
\hline & $\begin{array}{l}\text { Avail. N } \\
\text { (kg/ha) }\end{array}$ & $\begin{array}{l}\text { Avail. P } \\
\text { (kg/ha) }\end{array}$ & $\begin{array}{l}\text { Avail. K } \\
\text { (kg/ha) }\end{array}$ & $\begin{array}{l}\text { Avail. N } \\
\text { (kg/ha) }\end{array}$ & $\begin{array}{l}\text { Avail. P } \\
\text { (kg/ha) }\end{array}$ & $\begin{array}{l}\text { Avail. K } \\
\text { (kg/ha) }\end{array}$ \\
\hline $\mathrm{T}_{1}$ :Rice-Wheat & 216.7 & 13.8 & 213 & 221.0 & 13.8 & 214 \\
\hline $\mathrm{T}_{2}$ : Hyb. Rice-Wheat & 225.2 & 14.5 & 215 & 229.5 & 13.5 & 217 \\
\hline $\begin{array}{l}T_{3} \text { : Hyb. Rice-Wheat- } \\
\text { Green gram }(G+R)\end{array}$ & 255.0 & 14.8 & 221 & 263.5 & 14.9 & 223 \\
\hline $\mathrm{T}_{4}$ :Maize-Wheat & 221.0 & 13.6 & 211 & 225.2 & 13.7 & 212 \\
\hline $\begin{array}{l}\text { T}_{5} \text { : Maize-Mustard- } \\
\text { Onion }\end{array}$ & 216.7 & 13.5 & 214 & 221.0 & 13.4 & 215 \\
\hline $\begin{array}{l}\text { T}_{6} \text { : Maize-Mustard- } \\
\text { Green gram }(\mathbf{G}+\mathbf{R})\end{array}$ & 246.5 & 14.2 & 219 & 255.0 & 13.3 & 221 \\
\hline $\begin{array}{l}\text { T: Maize+Greengram- } \\
\text { Potato-Wheat }\end{array}$ & 233.7 & 13.8 & 215 & 238.0 & 13.6 & 216 \\
\hline $\begin{array}{l}\text { T8:Maize+Black gram- } \\
\text { Potato-Onion }\end{array}$ & 238.0 & 14.0 & 217 & 242.2 & 14.1 & 218 \\
\hline $\begin{array}{l}\text { T9: Maize-Garlic-Green } \\
\operatorname{gram}(\mathbf{G}+\mathbf{R})\end{array}$ & 250.7 & 14.4 & 220 & 259.2 & 14.5 & 222 \\
\hline$T_{10}:$ Rice-Wheat-Okra & 216.7 & 13.6 & 213 & 225.2 & 13.7 & 215 \\
\hline SEM \pm & 12.02 & 0.44 & 7.67 & 12.82 & 0.47 & 7.85 \\
\hline $\mathrm{CD}(\mathrm{P}=0.05)$ & 34.97 & 1.28 & 22.24 & 37.20 & 1.37 & 22.79 \\
\hline
\end{tabular}

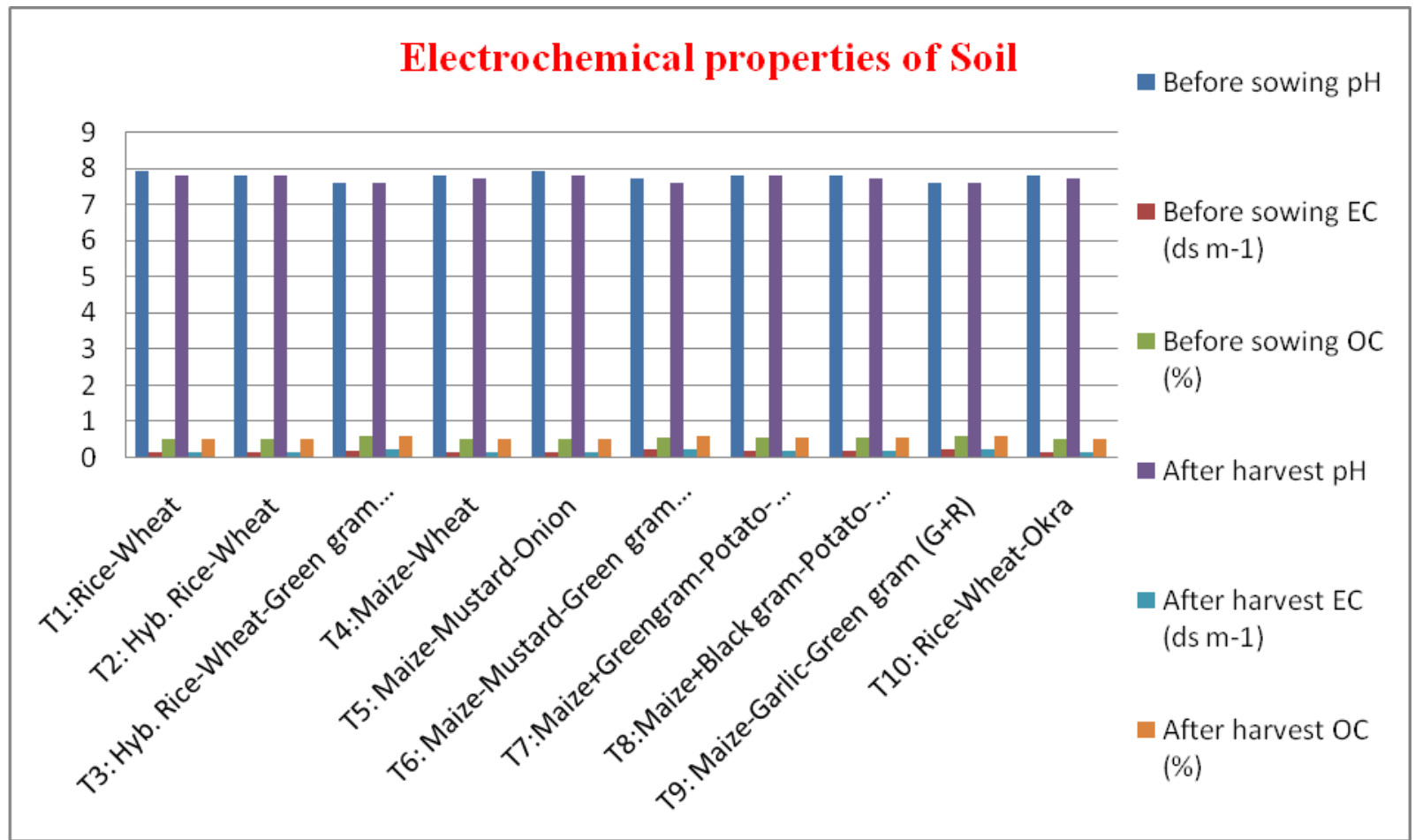


Effect on available nutrient status in soil (after harvest)

Improvement in available nitrogen, phosphorus and potassium status was also observed in all crop rotations in comparison to initial values. Maximum available nitrogen status $(263 \mathrm{~kg} / \mathrm{ha})$ was recorded in Hyb. Ricewheat-greengram $(\mathrm{G}+\mathrm{R})\left(\mathrm{T}_{3}\right)$ followed by Maize-garlic- greengram $(\mathrm{G}+\mathrm{R})(259 \mathrm{~kg} / \mathrm{ha})$ $\left(\mathrm{T}_{9}\right)$. Maximum available phosphorus status $(14.90 \mathrm{~kg} / \mathrm{ha})$ was recorded in Hyb. Ricewheat-greengram $(\mathrm{G}+\mathrm{R})\left(\mathrm{T}_{3}\right)$ followed by Maize-garlic- greengram $(\mathrm{G}+\mathrm{R})(14.55 \mathrm{~kg} / \mathrm{ha})$ $\left(\mathrm{T}_{9}\right)$. Maximum available phosphorus status $(223 \mathrm{~kg} / \mathrm{ha}$ ) was recorded in Hyb. Rice-wheatgreengram $(\mathrm{G}+\mathrm{R})\left(\mathrm{T}_{3}\right)$ followed by Maizegarlic- greengram $(\mathrm{G}+\mathrm{R})(222 \mathrm{~kg} / \mathrm{ha})\left(\mathrm{T}_{9}\right)$. Porpavai et al., (2011) also reported that inclusion of legumes in cropping system improved soil available NPK (Table 2).

The fertility status of the soil indicated beneficial impact of crop diversification/ intensification on soil fertility. Its effect was more pronounced in the case of Hyb. Ricewheat- greengram $(\mathrm{G}+\mathrm{R})$ among rice based cropping sequence, while Maize-garlicgreengram $(\mathrm{G}+\mathrm{R})$ in the case of maize based cropping sequence.

\section{References}

Anderson R I. 2005. Are some crops synergistic to following crops? Agron. J. 97(1): 7-10.

Bhandari, A. L., J. K. Ladha, H. Pathak, D. Dawe, and R. K. Gupta. 2003. Trends in yield and soil nutrient status in a longterm rice-wheat experiment in IndoGangetic Plains of India. Soil Science Society of America Journal 66: 162170.

Bijay-Singh, Yadvinder-Singh, P. Imas, and X. Jian-Chang. 2003. Potassium nutrition of the rice-wheat cropping system. Advances in Agronomy 81:203-259.

Dobermann, A., K. G. Cassman, C. P. Mamaril, and J. E. Shesby. 1999. Management of phosphorus, potassium, and sulfur in intensive irrigated lowland rice. Field Crops Research 56: 113-118.

Gangwar B, Katyal V and Anand K. V. 2004.Stability and efficiency of cropping system in Chhattishgarh and Madhya Pradesh, Indian. J. Agric. Sci. 74 (10): 521-528.

Kharub, A.S., Chauhan, D.S., Sharma, R.K., Chhokar, R.S. and Tripathi, S.C. (2003). Diversification of rice - wheat system for improving soil fertility and productivity. Indian Journal of Agronomy. 48(3): 149 -152.

Kumar, Alok and D.S. Yadav, 1993. Effect of long term fertilization on soil fertility and yield under rice-wheat cropping system. J. Indian Soc. Soil Sci. 41(1): 178-180.

Ladha, J. K., D. Dawe, H. Pathak, A. T. Padre, R. L. Yadav, Bijay-Singh, Yadvinder-Singh, Y. Singh, P. Singh, A. L. Kundu, R. Sakal, N. Ram, A. P. Regmi, S. K. Gami, A. L. Bhandari, R. Amin, C. R. Yadav, S. Bhattarai, S. Das, H. P. Aggarwal, R. K. Gupta, and P. R. Hobbs. 2003. How extensive are yield declines in long-term rice-wheat experiments in Asia? Field Crops Research 81: 159-180.

Porpavai, S., Devasenapathy, P., Siddeswaran K. and Jayaraj, T. (2011). Impact of various rice based cropping systems on soil fertility, Journal of Cereals and Oilseeds Vol. 2(3): 43-46.

Reddy B N and Suresh G. 2009. Crop diversification with oilseed crops formaximizing productivity, profitability and resource conservation. Indian $\mathrm{J}$. Agron. 54(2): 206-14.

Regmi, A. P., J. K. Ladha, E. Pasquin, H. Pathak, P. R. Hobbs, L. L. Shrestha, D. 
B. Gharti, and E. Duveiller. 2002. The role of potassium in sustaining yields in a long-term rice-wheat experiment in the Indo-Gangetic Plains of Nepal. Biology and Fertility of Soils 36: 240 247.

Srivastava, S., T. R. Rupa, A. Swarup, and D. Singh. 2002. Effect of longterm fertilization and manuring on potassium release properties in a Typic Ustochrept. Journal of Plant Nutrition and Soil Science 165: 352-356.

Timsina, J., and D. J. Connor. 2001. Productivity and management of rice- wheat cropping systems: Issues and challenges. Field Crop Research 69: 93132.

Yadav, R.L., Kamta Prasad, Gangwar, K.S., and Dwivedi, B.S., 1998. Cropping system and resource use efficiency. Indian J. Agric. Sci. 68: 548-558.

Yadvinder-Singh, Bijay-Singh, and J. Timsina. 2005. Crop residue management for nutrient cycling and improving soil productivity in ricebased cropping systems in the tropics. Advances in Agronomy 85: 269-407.

\section{How to cite this article:}

Rentapalli Balaji, Karam Husain and Uma Shankar Tiwari. 2018. Study of Electrochemical Properties of Soil and Nutrient Status of Rice and Maize based Cropping Sequences in Central Plain Zone of Uttar Pradesh. Int.J.Curr.Microbiol.App.Sci. 7(11): 203-208. doi: https://doi.org/10.20546/ijcmas.2018.711.024 